\title{
Metabolisme Energi Pakan pada Sapi Peranakan Ongole dan Sapi Peranakan Ongole x Limousin Jantan yang Mendapat Pakan Jerami Padi Fermentasi dan Konsentrat
}

\author{
Agung Purnomoadi, Nurhidayat dan Edy Rianto \\ Fakultas Peternakan Universitas Diponegoro, Semarang
}

\begin{abstract}
Abstrak
Suatu penelitian telah dilaksanakan dengan tujuan untuk mengkaji metabolisitas energi pakan pada sapi Peranakan Limousin dan sapi Peranakan Ongole jantan yang mendapatkan pakan jerami padi fementasi. Materi yang digunakan dalam penelitian ini berupa 4 ekor sapi Peranakan Ongole (PO) dan 4 ekor sapi Peranakan Ongole Limousin (POL) jantan dengan umur rata-rata 9 bulan. Bobot badan awal rata-rata sapi PO $109 \pm 16 \mathrm{~kg}$ $(\mathrm{CV}=10,8 \%)$ sapi POL $133 \pm 25 \mathrm{~kg}(\mathrm{CV}=14,13 \%)$. Pakan yang diberikan berupa jerami padi fermentasi (diberikan secara ad libitum) dan konsentrat (diberikan 2,1\% dari bobot badan). Rancangan percobaan yang digunakan adalah metode "Independent Sample Comparison". Parameter yang diamati adalah konsumsi dan matabolisabilitas energi pakan, serta pertambahan bobot badan harian $(\mathrm{PBBH})$. Hasil penelitian menunjukkan bahwa konsumsi energi pada sapi POL (74 MJ/hari) tidak berbeda nyata dengan konsumsi energi pada sapi PO (58,2 MJ/hari). Metabolisabilitas energi pada sapi POL dan PO juga tidak berbeda nyata $(\mathrm{P}>0,05)$, masing-masing $43,4 \%$ dan $38,4 \%$. PBBH pada sapi POL dan PO menunjukkan perbedaan yang nyata $(\mathrm{P}<0,05)$ masing-masing 0,47 dan $0,24 \mathrm{~kg} / \mathrm{hari}$. Disimpulkan bahwa sapi PO dan POL mempunyai kemampuan yang sama dalam memetabolisa energi pakan.
\end{abstract}

Kata Kunci: sapi jantan, bangsa, metabolisme energi

\section{Dietary Energy Metabolism in Ongole Grade and Ongole Grade x Limousin Bulls Fed Fermented Rice Straw and Concentrate}

\begin{abstract}
An experiment was carried out to study energy metabolisability in Limousin Grade and Ongole Grade bulls fed fermented rice straw. This experiment used 4 Ongole Grade $(O G)$ and 4 Ongole Grade $x$ Limousin (OGL) bulls, aged 9 mths. Ongole Grade bulls weighed $109 \pm 16 \mathrm{~kg}$, while OGL bulls weighed $133 \pm 25 \mathrm{~kg}$. The feeds given were fermented rice straw (offered ad libitum) and concentrate (fed at 2.1\% live weight). The breeds of cattle were compared to each other in an "Independent Sample Comparison" method. Parameters observed were energy intake, energy excretion through faeces, urine and methane, and live weight gain. The results showed that there was no significant difference $(P>0.05)$ between $O G$ and $O G L$ in energy intake $(58.2 \mathrm{MJ} / \mathrm{d} v \mathrm{~s} 74 \mathrm{MJ} / \mathrm{d})$, nor in energy metabolisability $(38,4 \%$ vs 43,4\%) The LWG of $O G(0,24 \mathrm{~kg} / \mathrm{d})$ was significantly $(P<0.5)$ lower than that of $O G L$ $(0,47 \mathrm{~kg} / \mathrm{d})$. It was concluded that being given fermented rice straw, OG and OGL bulls had similar ability in dietary energy metabolism.
\end{abstract}

Key Words: bull, breed, energy metabolism 


\section{PENDAHULUAN}

Usaha peternakan sapi potong di Indonesia saat ini berkembang pesat. Perkembangan peternakan tersebut didukung oleh pemerintah yang mendatangkan sapi Eropa (Bos taurus) diantaranya sapi Limousin. Salah satu faktor yang perlu diperhatikan dalam pengembangan sapi keturunan Bos taurus adalah bahwa sapi tersebut memerlukan pakan yang berkualitas baik. Perbedaan bangsa suatu ternak diduga akan menyebabkan perbedaan kemampuan ternak dalam memetabolisa energi, sehingga perlu dilakukan penelitian tentang hal ini.

Salah satu kendala yang dialami oleh banyak peternak di dalam usaha peternakan sapi adalah masalah penyediaan bahan pakan terutama hijauan. Penanggulangan masalah tersebut dapat diatasi dengan mengganti bahan pakan hijauan dengan limbah hasil pertanian, misalnya jerami padi. Kandungan nutrisi jerami padi kurang bagus demikian pula dengan kecernaannya. Salah satu usaha untuk meningkatkan daya cerna jerami padi adalah dengan fermentasi.

Produktivitas ternak antara lain dipengaruhi oleh tingkat metabolisme energi. Energi yang terdapat dalam bahan pakan tidak semuanya dapat digunakan oleh tubuh, tetapi energi tersebut dapat keluar berupa gas methana, feses, urin dan panas metabolisme tubuh. Tujuan dari penelitian ini adalah mengkaji metabolisme energi pada sapi Peranakan Ongole (PO) dan Peranakan Ongole x Limousin (POL) yang mendapatkan pakan jerami terfementasi. Hasil penelitian ini diharapkan dapat memberikan informasi tentang pemanfaatan energi pakan pada sapi PO dan sapi POL yang mendapat pakan jerami padi terfermentasi dan konsentrat.

\section{MATERI DAN METODE}

\section{Materi dan Peralatan Penelitian}

Materi yang digunakan dalam penelitian ini berupa 4 ekor sapi PO dan 4 ekor sapi POL jantan dengan umur rata-rata
9 bulan. Bobot badan awal rata-rata sapi PO adalah $109 \pm 12 \mathrm{Kg}(\mathrm{CV}=10,9 \%)$, dan sapi POL adalah $133 \pm 19 \mathrm{Kg}(\mathrm{CV}=14,14 \%)$. Sapi-sapi tersebut ditempatkan pada kandang yang dilengkapi dengan tempat pakan, tempat konsentrat dan tempat minum.

Bahan pakan yang digunakan dalam penelitian ini adalah jerami fermentasi dan konsentrat. Jerami difermentasikan selama 21 hari dengan menggunakan probiotik. Jerami tersebut juga ditambahi dengan bekatul sebelum difermentasikan. Jumlah pemberian konsentrat adalah $2,1 \%$ dari bobot badan (BB).

\section{Rancangan Percobaan}

Pecobaan ini menggunakan metode "Independent Sample Comparison", yaitu membandingkan 2 kelompok sapi dengan genetik yang berbeda sebagai materi penelitian. Pada penelitian ini ada 2 materi yang dibandingkan, yaitu sapi Peranakan Ongole (4 ekor) dan sapi Peranakan Ongole $\mathrm{x}$ Limousin (4 ekor)

\section{Parameter Penelitian}

Parameter yang diamati adalah jumlah konsumsi Bahan Kering (BK), dan bahan organik (BO), jumlah energi yang dikonsumsi, energi yang dikeluarkan melalui feses, energi yang dikeluarkan melalui urin, dan energi gas methana yang keluar. Jumlah gas methana yang dikeluarkan diukur dengan menggunakan "Face Mask Method" (cerobong muka) yang dihubungkan dengan " $\mathrm{CH} 4$ analyser" (Alat pengukur $\mathrm{CH} 4$ dengan merk "Horiba Ltd, Japan'). Metabolisabilitas energi dihitung dengan cara pengurangan jumlah energi yang dikonsumsi dalam pakan dengan energi dalam feses, energi dalam urin dan energi methana.

\section{Prosedur Penelitian}

Penelitian ini dilakukan dalam 3 tahap, yaitu, tahap adaptasi (4 minggu), tahap pendahuluan (1 minggu) dan tahap 
perlakuan (10 minggu). Selama tahap adaptasi, sapi diberi obat cacing untuk menghilangkan gangguan parasit cacing di tubuh ternak sapi. Pada tahap ini juga dilakukan adaptasi pakan penelitian secara bertahap untuk membiasakan sapi mengkonsumsi pakan tersebut.

Kegiatan yang dilakukan selama tahap pendahuluan adalah penempatan materi penelitian di kandang. Pakan yang diberikan pada tahap pendahuluan ini telah sesuai dengan perlakuan pakan yang dicobakan. Hal ini bertujuan untuk menghilangkan pengaruh pakan sebelumnya. Pada akhir tahap pendahuluan dilakukan penimbangan bobot badan untuk mengetahui bobot badan awal sapi penelitian.

Pada periode perlakuan ternak diberi jerami padi secara ad libitum. Konsentrat diberikan berdasarkan bobot badan masingmasing ternak yaitu 2,1\% dari bobot badan. Konsentrat tersebut diberikan dua kali sehari, yaitu pada pukul 07.00 dan 15.00 WIB. Air minum diberikan secara ad libitum. Bahan pakan yang digunakan dalam penelitian ini adalah jerami padi fermentasi dan konsentrat. Kandungan nutrisi bahan pakan tersebut dapat dilihat pada Tabel 1.

Tabel 1. Kandungan Nutrisi Bahan Pakan Penelitian

\begin{tabular}{lcccccccc}
\hline & $\mathrm{BK}$ & $\mathrm{Abu}$ & $\mathrm{BO}$ & $\mathrm{LK}$ & $\mathrm{PK}$ & $\mathrm{SK}$ & $\mathrm{BETN}$ & \multirow{2}{*}{$\begin{array}{c}\text { Energi } \\
\text { Bahan Pakan }\end{array}$} \\
\cline { 2 - 7 } & \multicolumn{5}{c}{$\ldots \ldots \ldots \ldots \ldots \ldots \ldots \ldots(\%) \ldots \ldots \ldots \ldots \ldots \ldots$} & MJ $/ \mathrm{kg}$ \\
\hline Jerami Fer & 85,56 & 31,03 & 54,54 & 1,09 & 9,84 & 29,41 & 45,23 & 14,46 \\
Konsentrat & 89,97 & 16,04 & 72,20 & 7,56 & 13,21 & 15,7 & 51,78 & 17,20 \\
\hline
\end{tabular}

Keterangan :

$\mathrm{BK}=$ Bahan Kering; $\mathrm{BO}=$ Bahan Organik; $\mathrm{LK}=$ Lemak Kasar $\quad \mathrm{PK}=$ Protein Kasar; $\mathrm{SK}=$ Serat Kasar; BETN = Bahan Ekstrak Tanpa Nitrogen; Fer $=$ Fermentasi

Total koleksi feses dan urin yang dikeluarkan oleh ternak dilakukan selama 4 hari berturut-turut pada awal minggu periode perlakuan. Total koleksi dilakukan pada pukul 07.00 WIB dan berakhir pada jam yang sama di hari berikutnya, begitu seterusnya sampai 4 hari berturut-turut. Hasil penampungan feses dan urin pada pagi harinya ditimbang dan kemudian diambil sampel. Pengambilan sampel pada feses dan urin dilakukan setelah pengadukan hingga merata.

Sampel urin diambil secara proporsional setiap hari. Sampel pada hari pertama diambil kurang lebih $250 \mathrm{~g}$. Pengambilan sampel urin pada hari berikutnya disesuaikan proporsinya dengan pengambilan pada hari pertama. Hasil total koleksi urine selama 4 hari dicampur dan diaduk hingga homogen, kemudian diambil sampel untuk dianalisis. Sampel feses diambil kurang lebih $1 \mathrm{~kg}$. Pengambilan sampel feses pada berikutnya, disesuaikan proporsinya dengan pengambilan pada hari pertama. Hasil total koleksi feses selama 4 hari kemudian dikeringkan. Feses yang kering ditumbuk dan dicampur hingga homogen, kemudian diambil sampel untuk dianalisis kandungan energi. Kandungan bahan kering feses yang dikeluarkan diukur setiap hari dengan cara dioven dengan suhu $105{ }^{0} \mathrm{C}$ selama 4 jam.

Pengukuran emisi gas methana dilakukan salama 2 hari dengan lama pengukuran 10 menit tiap sapi dan interval selama 3 jam dan pertambahan bobot badan. Jumlah methana yang keluar (liter/hari) dikonversikan menjadi kkal/hari dengan mengalikan 9,45. Konversi energi terkonsumsi, tercerna dan termetabolisa dihitung dengan membagi energi yang terkonsumsi, tercerna dan termetabolisa dengan pertambahan bobot badan harian. Data yang diperoleh dianalisa dengan uji tstudent (Sudjana, 1989). 


\section{HASIL DAN PEMBAHASAN}

\section{Konsumsi dan Kecernaan Pakan}

Hasil rata-rata pertambahan bobot badan harian $(\mathrm{PBBH})$, konsumsi bahan kering (BK), Pengeluaran BK feses, dan BK tercerna ditampilkan pada Tabel 2.

Konsumsi BK total, BK konsentrat dan BK jerami fermentasi per satuan bobot badan tidak menunjukkan perbedaan yang nyata $(\mathrm{P}>0,05)$. Sumbangan $\mathrm{BK}$ jerami fermentasi terhadap konsumsi BK total pada sapi PO dan POL masing-masing sebesar 33,01 dan 27,21\%. Sumbangan BK konsentrat terhadap konsumsi BK total pada sapi PO adalah $66,99 \%$, dan pada sapi POL adalah sebesar $72,79 \%$.

Tabel 2. Rata-rata PBBH, Konsumsi BK Total, Konsumsi BK Jerami, Konsumsi BK Konsentrat, Pengeluaran BK Feses, Konsumsi BK Tercerna dan BK Tercerna

\begin{tabular}{lccc}
\hline \multirow{2}{*}{\multicolumn{1}{c}{ Parameter }} & \multicolumn{2}{c}{ Bangsa Sapi } & \\
\cline { 2 - 3 } & PO & POL & Beda \\
\hline PBBH (kg/hari) & 0,24 & 0,47 & $*$ \\
Konsumsi BK Total (g/kg BB) & 28,60 & 29,66 & \\
Konsumsi BK Jerami (g/kg BB) & 9,44 & 8,07 & \\
Konsumsi BK Konsentrat (g/kg BB) & 19,16 & 21,59 & $\mathrm{~ns}$ \\
Pengeluaran BK Feses $(\mathrm{g} / \mathrm{kg} \mathrm{BB})$ & 12,94 & 12,85 & $\mathrm{~ns}$ \\
Konsumsi BK Tercerna $(\mathrm{g} / \mathrm{kg} \mathrm{BB})$ & 15,66 & 16,81 & $\mathrm{~ns}$ \\
Kecernaan BK $(\%)$ & 54,76 & 56,68 & $\mathrm{~ns}$ \\
\hline Keterangan ; $*$ : Berbeda nyata $(\mathrm{P}<0,05)$ dan ns: Tidak berbeda nyata $(\mathrm{P}>0,05)$
\end{tabular}

BK feses antara kedua bangsa sapi tidak berbeda nyata $(\mathrm{P}>0,05)$. Pengeluaran BK feses pada sapi PO adalah $12,94 \mathrm{~g} / \mathrm{kg}$ $\mathrm{BB}$, dan pada sapi POL adalah $12,85 \mathrm{~g} / \mathrm{kg}$ BB. Kejadian ini sesuai dengan kenyataan bahwa konsumsi BK total kedua bangsa sapi juga tidak berbeda nyata $(\mathrm{P}>0,05)$.

Kecernaan BK pada kedua bangsa sapi tidak berbeda nyata $(\mathrm{P}>0,05)$. Persentase kecernaan BK pada sapi PO dan POL masing-masing adalah $54,76 \%$ dan $56,68 \%$. Tidak adanya perbedaan yang nyata antara sapi PO dan sapi POL dalam kemampuan mencerna BK, menunjukkan bahwa saluran pencernaan pada kedua bangsa sapi tersebut mempunyai kemampuan yang sama dalam menampung digesta, dan laju pakan yang sama dalam saluran pencernaan. Hal tersebut juga diperkuat dengan tidak adanya perbedaan pada faktor-faktor yang mempengaruhi kecernaan menurut Campbell dan Lasley (1985), yaitu temperatur lingkungan, bentuk fisik pakan dan pemanasan bahan pakan.

\section{Metabolisabilitas Energi}

Rata-rata konsumsi energi pakan, pengeluaran energi dalam feses, urin, gas methana, energi tercerna dan energy termetabolisa dapat dilihat pada Table 3 . Konsumsi energi per satuan bobot badan pada sapi PO dan POL tidak menunjukkan perbedaan yang nyata $(\mathrm{P}>0,05)$, masingmasing sebesar 0,537 dan $0,555 \mathrm{MJ} /$ hari. Tidak adanya perbedaan konsumsi energi antara sapi PO dan POL ini mengindikasikan bahwa kapasitas saluran pencernaan kedua bangsa sapi tersebut juga tidak berbeda.

Kandungan energi yang keluar lewat feses per satuan bobot badan pada sapi PO dan POL masing masing 0,205 $\mathrm{MJ} /$ hari atau sebesar 38,17\%, sedangkan pada sapi POL $0,198 \mathrm{MJ} /$ hari atau sebesar $35,68 \%$ dari total energi yang dikonsumsi. Kecernaan energi pada penelitian lebih tinggi dari yang dilaporkan Bondi (1987), bahwa pengeluaran energi lewat feses berkisar antara $45-50 \%$ dari total konsumsi energi. Eksresi feses tergantung pada beberapa faktor antara lain konsumsi pakan, kualitas pakan, dan jenis ternak (Bondi, 1987). 
Tabel 3. Rata-rata Konsumsi Energi Pakan, Pengeluaran Energi, Konsumsi Energi Tercerna, Kecernaan Energi, Konsumsi Energi Termetabolisa dan Metabolisabilitas Energi

\begin{tabular}{lccc}
\hline & \multicolumn{2}{c}{ Bangsa Sapi } & \\
\cline { 2 - 3 } \multicolumn{1}{c}{ Parameter } & PO & POL & Beda \\
\hline Konsumsi Energi Total (MJ/hari) & 58,2 & 74 & $\mathrm{~ns}$ \\
Konsumsi Energi per kg BB (MJ/hari) & 0,537 & 0,555 & $\mathrm{~ns}$ \\
Pengeluaran Energi per kg BB & & & \\
$\quad$ Feses (MJ/hari) & 0,205 & 0,198 & $\mathrm{~ns}$ \\
$\quad$ Urin (MJ/hari) & 0,061 & 0,063 & $\mathrm{~ns}$ \\
$\quad$ Gas Methana (MJ/hari) & 0,065 & 0,053 & $*$ \\
& & & $\mathrm{~ns}$ \\
Konsumsi Energi Tercerna Total (MJ/hari) & 36 & 47,6 & $\mathrm{~ns}$ \\
Konsumsi Energi Tercerna per kg BB (MJ/hari) & 0,332 & 0,357 & $\mathrm{~ns}$ \\
Kecernaan Energi (\%) & 61,8 & 64,3 & $\mathrm{~ns}$ \\
Konsumsi Energi Termetabolisa Total (MJ/hari) & 22,4 & 32,1 & $\mathrm{~ns}$ \\
Konsumsi Energi Termetabolisa (MJ/kg BB/hari) & 0,206 & 0,241 & $\mathrm{~ns}$ \\
Metabolisabitas Energi (\%) & 38,4 & 43,4 & \\
\hline Keterangan : & &
\end{tabular}

Keterangan : ns : Tidak berbeda nyata $(\mathrm{P}>0,05)$

* : Berbeda nyata $(\mathrm{P}<0,05)$

Kandungan energi yang keluar lewat urin untuk sapi PO dan POL masing-masing adalah $0,061 \mathrm{MJ} /$ hari atau sebesar $11,36 \%$ dan $0,063 \mathrm{MJ} /$ hari atau sebesar $11,35 \%$ dari total konsumsi energi. Pengeluaran energi lewat urin lebih tinggi dari yang dilaporkan Van Soest (1994), bahwa pengeluaran energi lewat urin berkisar antara 3-5\% dari total energi terkonsumsi. Kandungan energi yang keluar lewat gas methana per satuan bobot badan pada sapi PO dan POL menunjukkan perbedaan yang nyata $(\mathrm{P}<0,05)$, masing-masing adalah 0,065 dan $0,053 \mathrm{MJ} / \mathrm{kg} \mathrm{BB} /$ hari atau sebesar 12,10 dan $9,55 \%$ dari total energi yang dikonsumsi. Jumlah pengeluaran tersebut lebih besar dari yang dinyatakan oleh Van Soest (1994), bahwa pengeluaran energi lewat gas methana berkisar antara 5-12\%. Pengeluaran gas methana antara lain dipengaruhi oleh kualitas nutrisi pakan, kandungan serat kasar, konsumsi pakan dan kecernaan pakan (Holter dan Young, yang disitasi oleh Kurihara et al., 1997). Dijelaskan oleh Shibata et al. (1994) bahwa konsumsi pakan yang tinggi cenderung akan meningkatkan pengeluaran gas methana, dan kualitas pakan yang baik cenderung akan menurunkan pengeluaran gas methana.
Data pada Tabel 4 menunjukkan bahwa tingkat kecernaan energi pada sapi PO dan POL pada penelitian ini tidak berbeda nyata $(\mathrm{P}>0,05)$, masing-masing sebesar $61,8 \%$ dan $64,3 \%$. Hal ini sejalan dengan kecernaan BK yang juga tidak berbeda nyata (Tabel 3). Faktor-faktor yang mempengaruhi kecernaan antara lain kualitas pakan, jumlah yang dikonsumsi serta kecepatan alir pakan dalam saluran pencernaan (Ranjhan dan Pathak, 1989).

Persentase energi termetabolisa pada penelitian ini tidak berbeda nyata antara sapi PO dan sapi POL, yaitu masing-masing 38,4 dan 43,4\%. Angka tersebut lebih rendah dari yang dilaporkan Nonaka et al. (2001), yaitu sebesar 59\% dari jumlah energi terkonsumsi dengan materi sapi Holstein laktasi.

\section{Konversi Energi}

Konversi energi kasar adalah jumlah energi yang dimakan per satuan pertambahan bobot badan, pada sapi PO dan POL masing-masing sebesar 2,24 dan 1,18 $\mathrm{MJ} / \mathrm{kg} \mathrm{BB}$. Konversi energi yang tercerna untuk sapi PO dan POL masing-masing 1,38 dan $0,74 \mathrm{MJ} / \mathrm{kg}$, dan dari energi yang termetabolisa adalah sebesar 0,87 dan 0,51 
$\mathrm{MJ} / \mathrm{kg}$. Konversi energi dilihat dari pakan yang dikonsumsi dan energi yang tercerna berbeda nyata $(\mathrm{P}<0,05)$, sedangkan pada konversi energi termetabolisa tidak berbeda nyata $(\mathrm{P}>0,05)$. Secara keseluruhan nilai konversi energi terkonsumsi, energi tercerna dan termetabolisa lebih baik pada sapi POL dibandingkan pada sapi PO. Rata-rata konversi energi, konversi energi tercerna dan konversi energi termetabolisa dapat dilihat pada Tabel 4.

Tabel 4. Rata-rata Konversi Energi Terkonsumsi, Konversi Energi Tercerna dan Konversi Energi Termetabolisa.

\begin{tabular}{llcc}
\hline \multirow{2}{*}{ Parameter } & \multicolumn{2}{c}{ Bangsa Sapi } & \\
\cline { 2 - 3 } & PO & POL & \multirow{2}{*}{ Beda } \\
\hline Konversi Energi Terkonsumsi (MJ/kg BB) & 2,24 & 1,18 & $*$ \\
Konversi Energi Tercerna (MJ/kg BB) & 1,38 & 0,76 & $*$ \\
Konversi Energi Termetabolisa (MJ/kg BB) & 0,87 & 0,51 & ns \\
\hline
\end{tabular}

Keterangan : * : berbeda nyata $(\mathrm{P}<0,05)$

ns: tidak berbeda nyata

Sapi PO dan POL, konversi PK terkonsumsi per satuan pertambahan bobot badan masing-masing adalah sebesar 16,9 dan 8,8, untuk konversi PK yang tercerna adalah sebesar 9,76 dan 5,07, dan konversi PK yang termetabolisa adalah sebesar 6,32 dan 3,70. Konversi PK untuk sapi PO lebih rendah dari sapi POL. Hal ini menunjukkan bahwa kebutuhan PK sapi PO untuk hidup pokok lebih tinggi daripada yang dibutuhkan sapi POL. Rendahnya kebutuhan nutrisi untuk hidup pokok berhubungan erat dengan laju metabolisme didalam jaringan tubuh (Ensminger, 1990). Laju metabolisme ini antara lain dipengaruhi oleh genetik (Crampton dan Harris, 1969).

\section{KESIMPULAN DAN SARAN}

\section{Kesimpulan}

Berdasarkan hasil penelitian dapat disimpulkan bahwa sapi POL dan sapi PO jantan yang mendapat pakan jerami fermentasi mempunyai kemampuan memetabolisa energi yang tidak berbeda.

\section{Saran}

Penelitian lebih lanjut mengenai pemanfaatan nutrisi pakan pada sapi PO dan sapi POL dengan menggunakan perlakuan yang berbeda perlu dilakukan, untuk mengkaji lebih lanjut potensi kedua bangsa sapi tersebut.

\section{DAFTAR PUSTAKA}

Bondi, A. A. 1987. Animal Nutrition. First Publising. John Wiley dan Sons, Chichester.

Campbell, J.R. dan J.F. Lasley. 1985. The Science of Animal that Serve Humanity. $2^{\text {nd }}$ Ed., Tata McGrawHill Publishing Co. Ltd., New Delhi.

Crampton, C.W. dan L. Harris. 1969. Applied Animal Nutrition $2^{\text {nd }}$ Ed. W. H. Freeman and Company, San Fransisco.

Kurihara, M., M. Shibata, F. Terada, T. Nishida, dan A. Purnomoadi. 1997. Methane production and its dietary manipulation in ruminants. Dalam : R. Onodera. H. Itabashi, K. Ushida, H. Yano dan Y. Sasaki. (Ed). Rumen Microbes and Digestive Physiology in Ruminant. Japan Scientific Societies Press, Tokyo dan S. Karger, A. G, Basel, Switzerland. Hal 199-208.

Nonaka, I., F. Itoh, A. Purnomoadi, K. Higuchi, O. Enishi, F. Terada dan Y. Obara, 2001. Energy metabolism in lactating cows treated with 
recombinant bovine somatotropin under high environmental temperature. Dalam: A. Chwalibog dan K. Jakobsen. (Ed). Energy Metabolism in Animals. EAAP Publication, Snekkersten, Denmark. Hal 397-400.

Ranjhan, S. K. dan N. N. Pathak. 1989. Management and Feeding of Buffaloes. Vicas Publishing House, Put, Ltd., New Delhi.
Shibata, M. 1994. Methane production in ruminants. Dalam : K. Minami, A. Mosier dan R. Sass (Ed). $\mathrm{CH}_{4}$ and $\mathrm{N}_{2} \mathrm{O}$ Global Emissions and Other Agricultural and Industrial Sources. NIAES Series 2. Hal 105-115.

Sudjana. 1989. Metoda Statistika. Edisi ke5. Penerbit Tarsito, Bandung.

Van Soest, P. J. 1994. Nutritional Ecology of the Ruminant. Second Edition. Comstock Publising Association A Division of Cornel University Press, Ithaca. 